\title{
Opportunity and Limits of Privacy Education of Children in Digitalizing Society: Reconsider ParentsChildren Relations through Privacy and Surveillance Practices
}

\author{
Fuat Güllüpınar \\ Anadolu University, Department of Sociology, Eskişehir, Turkey
}

\begin{abstract}
This research focuses on the risks that children may face on digital communication platforms and the ways to cope with these risks, improving the children's perceptions of privacy, as well as the principles of limiting an over-controlling super-supervision practice on children through parents' use of the Internet. For this purpose, a sociological analysis was made on the possibilities and limitations of children's autonomy and privacy on digital communication platforms by scanning field researches on children, internet, privacy and parent-child relationships of the digital age in the national and international area. The development and spread of digital communication platforms have expanded the communication networks of people by creating both diverse and multidimensional activity areas. As the communication network and its dimensions expanded, the rules of how and to what extent the communication forms of people would be realized began to take a vague and ambiguous form. It is not expected that the personal space, the sense of privacy and ethical codes that define the boundaries of communication would develop as fast as the means of communication. As a result, as a branch of digital platforms, the subject of new media in which social relations are experienced has brought about debates about personal and public space, surveillance and privacy and autonomy and ethics. If parents can make it a habit to act with some basic principles in their relationships with children in the digital world, children can establish a secure internet environment, an improved sense of privacy, and a parent-child relationship based on trust: Parents should follow these principles as they are guiding their children through digital communication platforms: Embracing and accepting the child's world, teaching children to be respectful while using communication tools; Formulating and experiencing screen-free times together; using parental control tools for computers and similar devices while reaching to an agreement with children about their limitations; Helping children manage their digital coverage and reputation on social media: Mentioning the Golden Rule... (Do not write or do something on Skype, Facebook or any other social media platform that you would not say/do while face to face with someone!); To determine the principles for dowloads and for the time to use the internet and where to use these tools; Instead of threatening to pull the plug, reassuring children that they can share things that might be frightening, doubtful, shameful and ridiculing for them.
\end{abstract}

Keywords: Parenting, digital society, childhood, privacy, surveillance. 


\section{THE WORLD CONFERENCE ON \\ SOCIAL SCIENCES \& HUMANITIES}

Barcelona, Spain
12-14 December, 2019

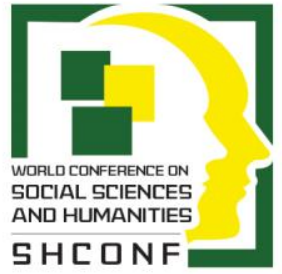

\section{Introduction}

This study, based on a sociological perspective, discusses which principles and values should be attributed to children's privacy education, which forms the basis of autonomy of their bodies, emotions, and thoughts in social conditions that have been digitalized by internet technologies and smartphones. Undoubtedly, in an environment where information and communication technologies are all around us, it has become almost impossible to treat privacy education independently of these developments. As a result of advances in communication technologies, the effects of privacy have expanded beyond the individual level and it is now under the influence of wider social and structural relationships.

Internet technologies, digital platforms and new social media tools, which have made their mark in the twentieth century and are ceaselessly spreading their influence in the twenty-first century, have now surrounded all areas of our daily lives. From communication to education, from trade to entertainment and games, the Internet has become an indispensable part of our social life. Depending on the constantly evolving technology, our forms of social relations change radically. Our lives can now be monitored continuously and transparently, and visual materials can be spread everywhere with the effect of internet technologies.

As with any technology, it is no longer possible to avoid internet technology due to its benefits and opportunities. However, it is an important need to bring certain limitations and barriers to internet use of children, especially considering the age groups. The internet can now be easily accessed through easy-to-access devices such as smartphones, making it more accessible to children. Children often have easy access to the internet from their home computers, school, friends' computers, cafes, their parents' or their mobile phones depending on their age. In particular, most studies have found that the internet carries more risk for young people aged 13-19 than for other age groups.

According to Turkish Statistical Institute's (TÜİK) Use of Household Information Technologies Survey made in 2018, the proportion of individuals using the Internet was 72.9\%.In 2018, computer and internet use was respectively $59.6 \%$ and $72.9 \%$ in the $16-74$ age groups. These percentages were $56.6 \%$ and $66.8 \%$ respectively in 2017 . While the percentages of computer and internet use were $68.6 \%$ and $80.4 \%$ for men in the $16-74$ age group, it was $50.6 \%$ and $65.5 \%$ for women. According to the report, eight out of ten households had internet access, according to the results of Use of Household Information Technologies Survey, 83.8\% of households had access to the internet as of April 2018. This percentage was $80.7 \%$ in the same month of 2017 . According to the said report, in 2018 , the rate of households who had broadband access to the Internet was $82.5 \%$. Accordingly, $44.5 \%$ of households accessed the Internet through a fixed broadband connection (ADSL, cable internet, fiber, etc.), while $79.4 \%$ accessed the internet through a mobile broadband 


\title{
THE WORLD CONFERENCE ON SOCIAL SCIENCES \& HUMANITIES
}

\author{
Barcelona, Spain
}

12-14 December, 2019

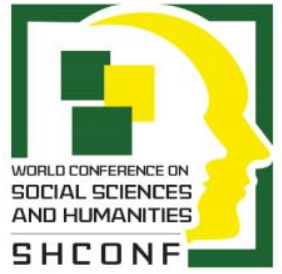

connection. The rate of households with broadband internet access was $78.3 \%$ in the previous year. The report found that $45.6 \%$ of individuals used e-government services in the twelve months covering the months of April 2017 and March 2018 to communicate with public institutions/organizations for personal purposes or to benefit from public services. This percentage was 42.4\% in the same period of the previous year (April 2016 - March 2017). Among the purposes of use, obtaining information from the web sites of public institutions took first place with $41.7 \%$. Meanwhile, the rate of online shopping has increased considerably by $29.3 \%$ ç The proportion of individuals in the 16-74 age group who ordered or purchased goods or services for personal use over the Internet was $29.3 \%$ in the twelve months covering April 2017 and March 2018. In the same period of the previous year (April 2016 - March 2017), this percentage was recorded as $24.9 \%$. The rate of online shopping by gender was $33.6 \%$ for men and $25 \%$ for women. These rates were $29 \%$ and $20.9 \%$ respectively in the same period of the previous year. $65.2 \%$ of individuals shopping online bought clothing and sports equipment. This was followed by travel tickets, car rental, etc. with $31.9 \%$, household goods (excluding furniture, toys, home appliances, etc. and consumer electronics) with $26.8 \%$, food or daily necessities with $22.1 \%$ and books, magazines, newspapers (including e-books) with $20.6 \%$. Clothing and sports tools were the most widely purchased products on the Internet, both by men and women, with $55.9 \%$ and $77.3 \%$ respectively. The lowest product group purchased by gender was medicine with $4.6 \%$ for men, and gaming software, other computer software and software updates for women with 2.8\% (TÜİK, 2018).

\section{Right to Privacy of Children and Internet}

According to a study on children's internet use, the fastest-growing group of internet users was determined to be preschool children (Microsoft, 2004; cited, Odabaş1, Kabakç1 and Çoklar, 2007: 77). Considering that the mental and social development of preschool children has not matured yet, preschool-age children constitute the most vulnerable and defenseless group in the face of internet technologies since children of this age group have not yet developed their mental abilities and social skills to protect themselves.

From six to eighteen years of age, children watch 16,000 hours of television, spend 4000 hours listening to radio and CDs, and spend several thousand hours at the cinema (Sanders, 1999). In addition to this, now equipped with internet technologies such as mobile phones, tablets and so on, we can estimate that the time children spend interacting with their parents or peers is increasingly declining. The comfort of presenting their children with these new media tools to take a break from the exhaustion of the urban work life causes children to engage more and more intensively with these tools. As Selda İçin Akçalı's points out in the article (2014) "Withering of Children in the Consumption Society", parents who do not have free time and are constantly tired are increasingly pushing the child towards the means of communication at home. Children spend most of their day under the "supervision" of these tools rather than their parents. The free time the family devotes to teaching children about life loses its essence as a time of sharing. As the price of the times the parents couldn't allocate to their children, most of the leisure time consists of consumption and entertainment. The media also takes over the area of teachings about life that the family has left empty. 


\title{
THE WORLD CONFERENCE ON \\ SOCIAL SCIENCES \& HUMANITIES
}

\author{
Barcelona, Spain
}

12-14 December, 2019

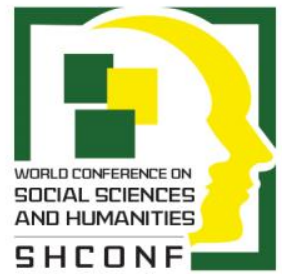

The right to privacy refers to a situation in which individuals themselves are fully autonomous in terms of the physical, intellectual and emotional aspects when participating in public life and in which direction, to what extent and how participation in social life is to be realized. From this point of view, the right and demand for privacy are one of the fundamental rights of people.

Privacy is also a conciliatory space that must be reached about what the boundaries between the individual and others or society are and what they should be. It can be said that the concept of a private space that recognizes the privacy of others and does not violate the individual's right to privacy is compatible with both Kantian ethics and democratic principles.

Privacy, which can be defined as physical, emotional, and intellectual autonomy, is certainly not absolute autonomy; it is a right that recognizes the autonomy, individuality and personal rights of others and recognizes the limits of the autonomy of others. The right to privacy is the precondition for the emotional, intellectual and physical development of the individual and the basis for the continuation of public life around "good" values.

Through an evaluation of privacy, which is the basis of our individual and social relations, we can summarize it as follows:

- Privacy is the immunity of the body. Privacy is a set of dynamic relationships that must be experienced under the guidance of ethical codes that form the basis of all our social relationships and that are based on mutual respect where collectivism and individuality intersects.

- Privacy is the inviolability of emotions and thoughts; emotions and thoughts are personal and they are essential elements of autonomy.

- Privacy means that personal information, content and images are under the control of the individual.

- Privacy is the ability of the individual to participate in the decision processes that concern the individual.

- Privacy is the ability to communicate with the people we want.

Research reveals that abuses against children in the world and in our country are often concealed due to the reactions such as shame, guilt and exclusion experienced by the victims of this abuse. It is very difficult to reach accurate statistics in this matter. This demonstrates the importance of developing children's autonomy and self-confidence through children's awareness training on privacy and the children building a strong communication link with their social environment based on trust. 


\section{THE WORLD CONFERENCE ON \\ SOCIAL SCIENCES \& HUMANITIES}

Barcelona, Spain

12-14 December, 2019

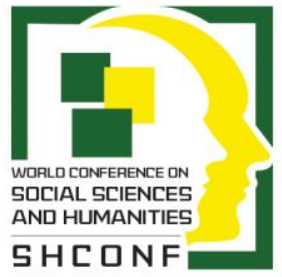

\section{Big Data and The Question of Privacy}

The close relationship between the storage, analysis and use of data on the internet makes storage a problem. In this respect, the debate on the relationship between storage and analysis is no different from that on arms laws: it is true that the gun itself does not kill anyone, there is a need for a finger to pull the trigger. However, when the number of weapons that people take in their hands increases, more triggers will be drawn. Similarly, the more data you allow to be stored, the more problems you create for privacy because it increases the chances of misuse of the data during analysis, which leads to an easy violation of one's privacy. As reported by Eirik Løkke (2018: 65), Taylor Armerding summarizes five major issues associated with Big Data on the internet;

Discrimination: Data analysis can cause difficulties for people with particular characteristics (ethnicity, gender, religion, etc.) to have the same opportunities as others.

Security breach: Your personal data may be leaked, with great opportunities for further processing. For example, nowadays there are search engines (Shodan), especially looking for webcam pictures of sleeping children.

Farewell to anonymity: Anonymous individuals can be identified by connecting to Big Data sets.

Broad powers conferred to the state: Big data also raises the question of what powers are assigned to monitoring and the organs of the state.

Unregulated Computing: Many personal data can be processed without any transparency or guarantee that computing is done correctly.

The Guardian announced that Raytheon (an American defense contractor) developed a software called "Rapid Information Overlay Technology", which freely uses easily accessible data from social platforms and IP addresses to monitor people and make their everyday lives transparent. Data analysts use Big Data to figure out our shopping trends, health status, sleep cycles, online shopping, friends, likes, places we go, movement patterns and so on. This information is individualized only in a few cases and mostly within the framework of intelligence work (Zwitter, 2019). The continuous recording of data over the internet and the digital footprint left by everyone have acutely brought forward a possibility that involves very important risks that enables misuse of individuals' and especially children's data.

As Çayçı and Çaycı (2017: 45) emphasize, the rapid developments in information and surveillance technologies cause new problems regarding privacy and confidentiality. With surveillance becoming a tool of social control, it has become an indispensable element of social order and social control. As surveillance has evolved in the historical process and with 


\section{THE WORLD CONFERENCE ON \\ SOCIAL SCIENCES \& HUMANITIES}

Barcelona, Spain

12-14 December, 2019

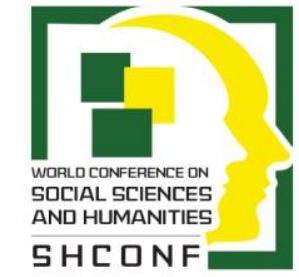

social changes, it has led to the transformation of both social structure and communication environments with the introduction of information technologies into daily life. These transformations have placed surveillance on the axis of interaction, interaction-based control and individualization beyond the traditional structure. In the light of technology, surveillance evolved from its traditional state, has now been replaced by computational surveillance.

\section{Parenting in the Digital Age}

It is clear that parenting in the digital world has become quite difficult for the regulation of social relations. Parents have to rigorously balance the opportunities and risks of the digital world concerning children's freedom and privacy, and carefully regulate their social relationships with children. This social relationship has to be of a nature that does not impair the autonomy and freedom of children and at the same time develops the children's sense of privacy. If parents can make these principles a habit in their relationships with their children regarding the digital world, they can establish a secure internet environment and a trust-based parent-child relationship:

- Adopting and accepting the world of children;

- To teach acting with respect while using communication tools;

- Formulate and experience activities together away from the screen;

- To agree with children on how to use parental control tools and their limits in computers and similar tools in order to encourage them to use the tools;

- To help manage digital coverage and reputation in social media;

- Reminding the rule of not saying or doing things on Skype, Facebook or any other social media platform if they cannot say or do those things in person;

- Agree on which music and games to download...

- To set policies on when to use the internet and where to use these tools;

- Instead of threatening to pull the plug, reassure them to share things that scare, embarrass or ridicule them or make them suspicious.

In the digital world, if parents can develop a trust-based social relationship with their children, they can provide a conducive environment to develop their internet security, privacy 


\section{THE WORLD CONFERENCE ON \\ SOCIAL SCIENCES \& HUMANITIES}

Barcelona, Spain

12-14 December, 2019

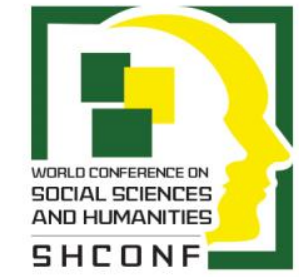

knowledge and practice. To improve children's internet security, privacy knowledge and skills, parents will have laid the foundation for safe internet use for their children if they can:

- Ensure that children make good use of existing security control and privacy/privacy settings;

- Children should be made aware of how to be safe especially when using social networking sites;

- To raise awareness of the risks of the digital world, to be safe, respectful and flexible, and to be a model for children when necessary;

- School-based education programs, internet security strategies in peer networks regarding how children should behave and speak in their relationships with adults should be utilized.

As a result, instead of defining morality as a situation unique to the internet, by defining moral principles that children should pay attention to only when they access the internet; It is very important to teach the general moral principles that we must obey while communicating and talking with others, to be a role-model and to ensure that these principles are the principles governing the relationship and communication rules in the internet world.

It is very important that parents are constantly open to communication so that children can talk openly and honestly about whether the common principles set out are being implemented and their activities on the internet. Perhaps the most important principle is the principle of the parent's openness to communication with the child.

\section{Conclusion}

It seems that as a result of the digital revolutions in the 21 st century, we are moving towards a social environment where we cannot consider the development of children's social and academic skills independent of their practice of using digital tools. We can determine that as children grow up, their choice and usage patterns in communication technologies will change patterns.

In the case of new media, producing solutions that build trust-based relationships without violating autonomy and the personal space will be the fundamental antidote to a logic of oversight that violates individual rights and includes undemocratic legal arrangements. As Binark and Bayraktutan (2013: 9) point out, instead of creating moral panic during the creation of legal principles regarding the dangerous aspects of the new media such as cybercrime and increased surveillance, ethical principles should be developed to guide the laws in the protection of personal rights and personal information and privacy.

Connected via smartphones or other means, the digital platforms use as a tool that helps children to learn about practices such as rules and boundaries, the discovery of knowledge, research and making friends should be encouraged to support their social development and 


\title{
THE WORLD CONFERENCE ON \\ SOCIAL SCIENCES \& HUMANITIES
}

\author{
Barcelona, Spain
}

12-14 December, 2019

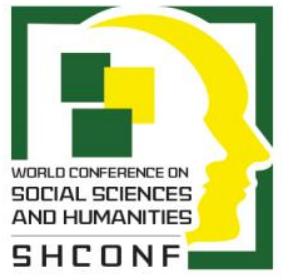

academic skills. Of course, these practices should be carried out while children are kept away from online risks. When we think of children and young people as smartphone users, it points to the necessity of designers to plan applications for them by considering all these opportunities and risks together.

In the digital age, parent-child relations, which is a dimension of people's social relations, were also affected by these developments in different ways. Being a parent and child in the digital age employs different meanings in the shadow of opportunities and risks provided by digital platforms. Both the evolving of leisure time practices to a time spent with digital tools and the fact that the socialization processes of the child begin to develop at the borders of the digital world are important indicators of how the digital world transforms the parent-child relationship.

It is clear that in the era of digitalization, where digital communication and internet use extends to infancy, the question of how the parent-child relationship evolves, how privacy and autonomy can be established for children and how to determine the parameters and principles in the regulation of a secure internet and parent-child relationship has become a very important issue. This research tries to determine how children can protect their privacy and autonomy while using digital communication platforms and what the basic principles of using a secure internet can be. In the digital age, there is an important need for more diverse and prevalent research to be conducted on how to protect the privacy and autonomy of children and young people in the world of internet, which is the basis of making internet use safe for children and young people in an environment where communication technologies surround us.

\section{References}

Binark, M. (5.12.2014) Dijital oyun dünyası ve yeni toplumsallaşma biçimleri. Aljazeera Türk. http://www.aljazeera.com.tr/gorus/dijital-oyun-dunyasi-ve-yenitoplumsallasmabicimleri (access: 01.04.2018).

Binark, M. ve Bayraktutan, G. (2013) Ayın Karanlık Yüzü: Yeni Medya ve Etik. İstanbul: Kalkedon yayınları.

Binark, M. ve Bayraktutan-Sütçü, G. (2008) Kültür Endüstrisi Ürünü Olarak Dijital Oyun. İstanbul: Kalkedon yayınları.

Çaycı, A. E. ve Çaycı, B. (2017) "Dijital İletişim Çağında Teknolojinin Açı̆̆a Çıkardıkları: Gözetim ve Mahremiyet," The Turkish Online Journal of Design, Art and Communication TOJDAC, 7 (1): 36-46.

Ghosh, A. K., Badillo-Urquiola, K., Guha, S., Laviola, J.J., Wisniewski, P. J. (2018) "Safety vs. Surveillance: What Children Have to Say about Mobile Apps for Parental Control,” In 


\section{THE WORLD CONFERENCE ON \\ SOCIAL SCIENCES \& HUMANITIES}

Barcelona, Spain

12-14 December, 2019

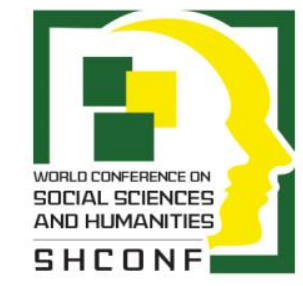

Proceedings of the 2018 CHI Conference on Human Factors in Computing Systems. pp.124138.

Hoover, S. M. (2013) “Dijital Çağda Çocuk Medyası (Ve Din): Zorluklar ve Koşullar,” I. Türkiye Çocuk ve Medya Kongresi Bildiriler Kitabı 2. (Ed. H. Yavuzer, R. Şirin) İstanbul: Çocuk Vakfı Yayınları, ss. 215-222.

Horst, H. A., Herr-Stephenson, B. and Robinson, L. (2010) "Media Ecologies," (Ed. M. Ito), Hanging out, Messing around and Geeking out: Kids Living and Learning with New Media Cambridge, MA: The MIT Press, s. 29-78. 48

İçin-Akçalı, S. (2014) “Tüketim Toplumunda Çocukluğun Yitişi,” Çocuk ve Medya (Der: Selda İçin-Akçalı) Ankara: Nobel yayıncılık, ss. 1-12.

Kupiainen, R., Suoninen, A. and Nikunen, K. (2012) "Between Public and Private: Privacy in Social Networking Sites," in Children, Risk and Safety on the Internet: Research and Policy Challenges in Comparative Perspective. (Eds. Sonia Livingstone, Leslie Haddon and Anke Görzig). Chicago: Policy Press. pp: 99-113.

Livingstone, S. (2009) Children and Internet. Cambridge: Polity Press. Murthy, T. (2012) "Towards a Sociological Understanding of Social Media: Theorizing Twitter". Sociology, 1059-1073.

Løkke, E. (2016) Mahremiyet: Dijital Toplumda Özel Hayat. İstanbul: Koc Üniversitesi Yayınlar1.

Odabaşı, F., Kabakçı, I. ve Çoklar, A. (2007) İnternet, Çocuk ve Aile. Ankara: Nobel Yayınc1lik.

Onur, B. (2005) “Çocuk yetiştirme”, Türkiye'de Çocukluğun Tarihi. Ankara: İmge Kitabevi, s. 253-283. Piotrowki, J. T., Vossen, H. G. M ve Valkenburg, P. M. (2013) "Medya ve Çocuk Gelişimi,” I. Türkiye Çocuk ve Medya Kongresi Bildiriler Kitabı 2. (Ed. H. Yavuzer, R. Şirin) İstanbul: Çocuk Vakfı Yayınları, ss. 49-67.

Stevenson, N. (2015) Medya Kültürleri: Sosyal Teori ve Kitle İletişimi. (Çev: G. Orhon; B. E. Aksoy), Ankara: Ütopya.

Steyer, J. P. (2014) FACEBOOK Çağında Çocuk Büyütmek. İstanbul: Doğan Egmont Yayınc1lık.

TÜİK (2018) Hanehalkı Bilişim Teknolojileri (BT) Kullanım Araştırması, http://www.tuik.gov.tr/PreHaberBultenleri.do?id=27819

Zwitter, A. (2019) “Büyük Veri Etiği," İletişim Hakkı ve Yeni Medya (Der. Tezcan Durna, Mutlu Binark ve Günseli Bayraktutan), Ankara: Um:ag Vakfı Yayınları. ss. 161-175. 